\title{
Relationship between forage neutral detergent fiber and non-fibrous carbohydrates on ruminal fermentation products and neutral detergent fiber digestibility in goats
}

Relación entre la fibra detergente neutra del forraje y los carbohidratos no fibrosos sobre los productos de la fermentación ruminal y digestibilidad de la fibra detergente neutra en cabras

Efeito da relação da fibra em detergente neutro advindo de forragem e carboidratos não fibrosos sobre os produtos da fermentação ruminal e digestibilidade da fibra em detergente neutro em caprinos

Ricardo M A Pinho ${ }^{1 *}$, Zoot, PhD; Edson M Santos ${ }^{2}$, Zoot, PhD; Juliana S de Oliveira ${ }^{2}$, Zoot, PhD; Gleidson G P de Carvalho $^{3}$, Zoot, PhD; Joyce P Alves ${ }^{2}$, Zoot; Alberto J da S Macêdo ${ }^{4}$, Zoot; Gildenia A Pereira ${ }^{2}$, Zoot, MSc; Danilo M Pereira $^{2}$, Zoot; Alexandre F Perazzo 5 , AG, PhD; Anderson de M Zanine ${ }^{6}$, Zoot, PhD.

${ }^{1}$ Departamento de Zootecnia, Universidade Federal de Viçosa, 36570-000 Viçosa, Minas Gerais, Brasil.

${ }^{2}$ Departamento de Zootecnia, Universidade Federal da Paraiba, 58397-000, Areia, Paraiba, Brasil.

${ }^{3}$ Departamento de Zootecnia, Universidade Federal Bahia, 40170-110, Salvador, Bahia, Brasil.

${ }^{4}$ Departamento de Ciência Animal, Universidade Federal de Campina Grande, 58708-110, Patos, Paraiba, Brasil.

${ }^{5}$ Bolsista DCR/FAPESB/CNPq, Universidade Estadual do Sudoeste da Bahia, Praça Primavera, 40, Bairro Primavera, Itapetinga, BA, 45700-000 Brasil.

${ }^{6}$ Departamento de Zootecnia, Universidade Federal do Maranhão, 65500-000 Chapadinha, Maranhão, Brasil.

(Received: September 22, 2017; accepted: October 28, 2018)

doi: 10.17533/udea.rccp.v32n2a06

\begin{abstract}
Background: There is a comprehensive understanding of the role of dietary fiber as a nutrient and its function during digestion in cattle. On the other hand, the role of fiber digestion in goats has not received similar attention. Objective: To evaluate the effects of different ratios of forage neutral detergent fiber (fNDF)
\end{abstract}

a To cite this article: Pinho RMA, Santos EM, de Oliveira JS, de Carvalho GGP, Alves JP, Macêdo AJdaS, Pereira GA, Pereira DM, Perazzo AF, Zanine AdeM. Relationship between forage neutral detergent fiber and non-fibrous carbohydrates on ruminal fermentation products and neutral detergent fiber digestibility in goats. Rev Colomb Cienc Pecu 2019; 32(2):126-138.

* Corresponding author: Ricardo Martins A Pinho. Departamento de Zootecnia, Universidade Federal de Viçosa, 36570-000 Viçosa, Minas Gerais, Brasil. Tel.: +558398079879. E-mail: ricardo-zootec@hotmail.com 
and non-fibrous carbohydrates (NFC) on ruminal fermentation products, and in vitro neutral detergent fiber (NDF) digestibility in goats. Methods: A $3 \times 5$ factorial arrangement in a completely randomized design with three fNDF levels $(100,190$, and $290 \mathrm{~g} / \mathrm{kg})$ and five NFC levels $(350,400,450,500$, and $550 \mathrm{~g} / \mathrm{kg})$ was used. The experiment was performed in vitro. Two ruminally fistulated goats were used as rumen liquid donors. Results: The ratios between $\mathrm{NDF}$ and NFC affected all ruminal parameters $(\mathrm{p}<0.05)$. Increasing NFC levels in diets containing 100 and $290 \mathrm{~g} / \mathrm{kg}$ fNDF resulted in linear increase $(\mathrm{p}<0.05)$ in ammonia concentration after $48 \mathrm{~h}$ fermentation. There was no adjustment of linear models $(\mathrm{p}>0.05)$ for $\mathrm{pH}$ values. Total volatile fatty acids (VFA) and their individual molar proportions were affected $(\mathrm{p}<0.05)$ at all $\mathrm{fNDF}$ and NFC levels. The NDF digestibility was not affected ( $\mathrm{p}>0.05$ ) by fNDF or NFC levels, except for diets containing $290 \mathrm{~g} / \mathrm{kg}$ fNDF, which were fit to a quadratic model $(\mathrm{p}<0.05)$. Conclusion: The relationship between fNDF and NFC concentrations affect the fermentation end products and in vitro NDF digestibility. NFC plays a more consistent role than $\mathrm{fNDF}$ in the ruminal microbial ecosystem of goats during in vitro fermentation.

Keywords: digestion, energy, microbial protein, physically effective fiber, rumen.

\section{Resumen}

Antecedentes: Aunque hay una amplia comprensión del papel que juega la fibra dietética como nutriente y su función durante la digestión en el ganado vacuno, el papel de la digestión de la fibra en las cabras no ha recibido una atención similar. Objetivo: Evaluar los efectos de diferentes proporciones de fibra detergente neutra proveniente del forraje (fNDF) y carbohidratos no fibrosos (NFC) sobre los productos de la fermentación ruminal y la digestibilidad in vitro de la fibra detergente neutra (NDF) en cabras. Métodos: Se utilizó un arreglo factorial de $3 \times 5$, distribuidos en un diseño completamente aleatorizado con tres niveles de fNDF (100, 190 y $290 \mathrm{~g} / \mathrm{kg}$ ) y cinco niveles de NFC (350, 400, 450, 500 y $550 \mathrm{~g} / \mathrm{kg})$. El experimento se realizó in vitro. Se utilizaron dos cabras fistuladas en rumen como donantes de líquido ruminal. Resultados: La relacion entre fNDF y NFC afectó todos los parámetros ruminales estudiados $(\mathrm{p}<0,05)$. El aumento de los niveles de NFC en dietas con 100 y $290 \mathrm{~g} / \mathrm{kg}$ de fNDF resultó en aumento lineal $(\mathrm{p}<0,05)$ de la concentración de amoníaco después de $48 \mathrm{~h}$ de fermentación. No hubo ajuste de modelos lineales $(\mathrm{p}>0,05)$ para valores de $\mathrm{pH}$. Los ácidos grasos volátiles totales y sus proporciones molares individuales se afectaron $(p<0,05)$ en todos los niveles de fNDF y NFC. La digestibilidad de NDF no fue afectada $(\mathrm{p}>0,05)$ por los niveles de fNDF ni NFC, con excepción de las dietas con $290 \mathrm{~g} / \mathrm{kg}$ fNDF, que se ajustaron a un modelo cuadrático $(\mathrm{p}<0,05)$. Conclusión: La relación entre las concentraciones de fNDF y NFC afecta los productos finales de fermentación y la digestibilidad in vitro de NDF. Los niveles de NFC juegan un papel más consistente que fNDF en el ecosistema microbiano ruminal de la cabra durante la fermentación in vitro.

Palabras clave: digestión, energía, fibra fisicamente efectiva, proteína microbiana, rumen.

\section{Resumo}

Antecedentes: Embora exista um compreensível entendimento do papel que a fibra dietética desempenha como nutriente e sua função durante a digestão em bovinos, o papel da digestão das fibras em caprinos não recebeu atenção semelhante. Objetivo: Avaliar os efeitos de diferentes relações da fibra em detergente neutro advindo de forragem (fNDF) e carboidratos não-fibrosos (NFC) sobre produtos da fermentação ruminal e digestibilidade in vitro da fibra em detergente neutro (NDF) em caprinos. Métodos: Utilizou-se um esquema fatorial de $3 \times 5$ distribuídos em um delineamento inteiramente casualizado com três níveis de fNDF (100, 190 e $290 \mathrm{~g} / \mathrm{kg})$ e cinco níveis de NFC $(350,400,450,500$ e $550 \mathrm{~g} / \mathrm{kg})$. O experimento foi realizado in vitro. Duas cabras fistuladas no rúmen foram utilizadas como doadoras de líquido ruminal. Resultados: As relações entre fNDF e NFC impactaram todos os parâmetros ruminais estudados $(\mathrm{p}<0,05)$. O aumento dos níveis de NFC em dietas contendo 100 e $290 \mathrm{~g} / \mathrm{kg}$ de fNDF resultou em um aumento linear $(\mathrm{p}<0,05)$ na concentração de amônia após $48 \mathrm{~h}$ de fermentação. Não houve ajuste de modelos lineares $(\mathrm{p}>0,05)$ para valores de $\mathrm{pH}$. Os ácidos graxos voláteis totais e suas proporções molares individuais foram afetados $(p<0,05)$ em todos os níveis de fNDF e NFC. A digestibilidade NDF não foi afetada $(\mathrm{p}>0,05)$ pelos níveis de fNDF e NFC, com exceção de dietas experimentais contendo $290 \mathrm{~g} / \mathrm{kg}$ fNDF, que foram ajustadas a um modelo quadrático $(\mathrm{p}<0,05)$. Conclusão: A relação entre as concentrações de fNDF e NFC afeta os produtos finais de fermentação e a digestibilidade in vitro de NDF de dietas experimentais. Os níveis de NFC desempenham um papel mais consistente do que o fNDF no ecossistema microbiano ruminal de cabras durante a fermentação in vitro.

Palavras-chave: digestão, energia, fibra fisicamente efetiva, proteína microbiana, rúmen. 


\section{Introduction}

Recommendations on the minimum total dietary neutral detergent fiber (NDF) and the minimum level of forage NDF (fNDF) for cows are $250 \mathrm{~g} / \mathrm{kg}$ of total $\mathrm{NDF}$, and $190 \mathrm{~g} / \mathrm{kg}$ of fNDF, respectively. These values have been defined through a compilation of research studies evaluating the performance of dairy cows under specific feeding conditions (NRC, 2001).

While there is a comprehensive understanding of the role that dietary fiber plays as a nutrient and its function during digestion in cattle, the role of fiber digestion in goats has not received similar attention (Lu et al., 2008). Goats differ from cattle in their feeding behavior, the level of fiber they ingest and their dietary selections (Reid et al., 1990). Based on voluntary dry matter intake (DMI), it is clear that the demand for energy and the physical capacity of the digestive tract direct the level of intake for a particular animal. Therefore, information obtained from other ruminant species cannot be simply extrapolated to goats.

Among the various lines of research related to ruminant nutrition, the study of the relationship between NDF and NFC is of great importance. Suitable NDF levels in a ruminant's diet during production are usually adjusted in order to maintain normal function of the rumen, maintain microbial protein synthesis (Xu et al., 2014), and optimize its intake and digestibility (Oliveira et al., 2011). Similarly, the NFC content has been considered in ruminant ration formulations as a nutritional criterion that is adjusted to obtain the appropriate fiber fraction in the feed (NRC, 2001). However, it is not known which of these components (fNDF or NFC) most affects the rumen microorganisms of goats.

For goats, there are no recommendations on the maximum and minimum values of fiber and NFC in the diet to maximize intake, animal performance and/or maintainance of normal conditions in the rumen. Thus, the evaluation of diets with different fNDF and NFC ratios under in vitro fermentation conditions can be used to determine the minimum and maximum quantities of fNDF and NFC that should be included in goat feed, since information on this topic is scarce.
Therefore, this study aimed to evaluate the effects of different forage neutral detergent fiber (fNDF) and non-fibrous carbohydrates (NFC) ratios on ruminal fermentation products and in vitro neutral detergent fiber (NDF) digestibility in goats.

\section{Material and methods}

\section{Ethical considerations}

The experimental procedures were approved by the Committee of Ethics on Animals at the Federal University of Paraiba (approval number: 2105/2013).

\section{Location}

In vitro experiments were conducted in the municipality of Areia, Paraiba (Brazil), located at an average altitude of $623 \mathrm{~m}$, with a $6^{\circ} 57^{\prime} 46^{\prime \prime}$ S latitude and $35^{\circ} 41^{\prime} 31^{\prime \prime} \mathrm{W}$ longitude.

\section{Animals}

Two ruminally fistulated goats, fed a total mixed ration (TMR) consisting of 60:40 forage to concentrate ratio on a DM basis, were used as rumen liquid donors. The animals were fed corn silage and a concentrate composed of ground corn, soybean meal and a mineral supplement.

Rumen fluid was collected $2 \mathrm{~h}$ after the morning feeding, filtered through four layers of cheesecloth, packed in a thermal bottle and immediately taken to the laboratory. The rumen fluid was transferred to $500 \mathrm{~mL}$ Erlenmeyer flasks, which were gassed for $20 \mathrm{~s}$ with anaerobic-grade $\mathrm{CO}_{2}$ Then, they were sealed with plastic wrap and placed at rest for $30 \mathrm{~min}$ in an environmental chamber SP LABOR (SP-500 model, Presidente Prudente, SP, Brasil) at $39^{\circ} \mathrm{C}$. After formation of liquid interfaces, the intermediate liquid was withdrawn in order to obtain an inoculum containing the most active microbial population (Oliveira et al., 2012).

\section{Experimental design}

The experiment consisted of a completely randomized design in a $3 \times 5$ factorial scheme with three levels of fNDF (100, 190, and $290 \mathrm{~g} / \mathrm{kg}$ ) and 
five NFC levels $(350,400,450,500$, and $550 \mathrm{~g} / \mathrm{kg}$ ), with three replicates each. The experimental diets were formulated using Tifton- 85 hay, ground corn, soybean meal, wheat bran, urea and starch (Table 1).

Table 1. Chemical composition of ingredients used to formulate the experimental diets.

\begin{tabular}{|c|c|c|c|c|c|c|}
\hline \multirow{2}{*}{ Item } & \multicolumn{6}{|c|}{ Ingredients (g/kg ) } \\
\hline & $\begin{array}{l}\text { Tifton } \\
\text { hay }\end{array}$ & $\begin{array}{l}\text { Ground } \\
\text { corn }\end{array}$ & $\begin{array}{c}\text { Soybean } \\
\text { meal }\end{array}$ & $\begin{array}{c}\text { Wheat } \\
\text { bran }\end{array}$ & Urea & Starch $^{2}$ \\
\hline DM & 858.8 & 876.4 & 883.7 & 880.0 & 975.7 & 887.7 \\
\hline $\begin{array}{l}\text { Organic } \\
\text { matter }\end{array}$ & 946.0 & 988.4 & 944.1 & 946.8 & - & 91.3 \\
\hline Ash & 54.0 & 11.6 & 55.9 & 53.2 & - & 8.7 \\
\hline $\begin{array}{l}\text { Crude } \\
\text { protein }\end{array}$ & 88.0 & 95.2 & 464.1 & 160.0 & 2810 & 4.9 \\
\hline $\begin{array}{l}\text { Ether } \\
\text { extract }\end{array}$ & 7.7 & 38.0 & 15.6 & 35.3 & - & 2.6 \\
\hline $\mathrm{NDF}^{1}$ & 731.0 & 283.3 & 133.6 & 440.0 & - & - \\
\hline NDFap $^{1}$ & 712.5 & 247.5 & 96.1 & 394.3 & - & - \\
\hline $\mathrm{NFC}^{1}$ & 3.61 & 582.0 & 300.0 & 303.6 & - & 990.6 \\
\hline
\end{tabular}

$\mathrm{DM}=$ dry matter; $\mathrm{g} / \mathrm{kg}$ on a fresh matter basis; ${ }^{1} \mathrm{NDF}=$ Neutral Detergent Fiber; NDFap $=$ Neutral Detergent Fiber corrected for ash and protein; NFC = Neutral Fiber Carbohydrate. ${ }^{2}$ Data from Brazilian Tables of Food Composition for Cattle (Valadares Filho et al., 2015).

Different combinations of fNDF and NFC levels were achieved through the use of experimental diets formulated to be isonitrogenous according to (NRC, 2007) (Tables 2 and 3).

Samples of Tifton-85 hay, ground corn, soybean meal and wheat bran used in the formulation of experimental diets were dried in a forced-air oven at $55^{\circ} \mathrm{C}$ for $72 \mathrm{~h}$, ground in a Wiley mill (Wiley mill, Arthur H. Thomas, PA, USA) with a 1-mm screen, and stored in plastic containers for further laboratory analyses. Dry matter (DM) was determined with method 934.01. Organic matter (OM) was determined by the ash method (method 924.05). Crude protein (CP) was calculated by determining the total nitrogen content using the micro-Kjeldhal technique (method 920.87), and using a fixed conversion factor (6.25). Ether extract (EE) was determined gravimetrically after extraction with petroleum ether in a Soxhlet apparatus (method 920.85), and acid detergent fiber (ADF) (method 973.18) as described by the AOAC
Table 2. Proportion of ingredients used to formulate the experimental diets ( $\mathrm{g} / \mathrm{kg} \mathrm{DM})$.

\begin{tabular}{|c|c|c|c|c|c|c|}
\hline \multirow{2}{*}{$\begin{array}{l}\text { Ingredients } \\
(\mathbf{g} / \mathbf{k g})\end{array}$} & \multirow{2}{*}{$\begin{array}{l}\text { fNDF } \\
(\mathrm{g} / \mathrm{kg})\end{array}$} & \multicolumn{5}{|c|}{ NFC (g/kg) } \\
\hline & & 350 & 400 & 450 & 500 & 550 \\
\hline Tifton hay & & 133.2 & 133.2 & 133.2 & 133.2 & 133.2 \\
\hline Ground corn & & 223.8 & 223.8 & 223.8 & 223.8 & 200.0 \\
\hline $\begin{array}{l}\text { Soybean } \\
\text { meal }\end{array}$ & 100 & 0.00 & 0.00 & 0.00 & 0.00 & 16.0 \\
\hline Wheat bran & & 643.0 & 590.0 & 525.0 & 440.0 & 364.0 \\
\hline Urea & & 0.00 & 0.00 & 4.0 & 8.0 & 10.0 \\
\hline Starch & & 0.00 & 53.0 & 114.0 & 195.0 & 276.8 \\
\hline Tifton hay & & 253.1 & 253.1 & 253.1 & 253.1 & 253.1 \\
\hline Ground corn & & 250.0 & 250.0 & 250.0 & 250.0 & 250.0 \\
\hline $\begin{array}{l}\text { Soybean } \\
\text { meal }\end{array}$ & 190 & 35.0 & 35.0 & 40.0 & 40.0 & 40.0 \\
\hline Wheat bran & & 451.9 & 380.0 & 296.0 & 216.9 & 140.0 \\
\hline Urea & & 0.00 & 1.9 & 5.9 & 10.0 & 14.0 \\
\hline Starch & & 10.0 & 80.0 & 155.0 & 230.0 & 302.9 \\
\hline Tifton hay & & 386.3 & 386.3 & 386.3 & 386.3 & 386.3 \\
\hline Ground corn & & 290.0 & 290.0 & 290.0 & 125.0 & 0.00 \\
\hline $\begin{array}{l}\text { Soybean } \\
\text { meal }\end{array}$ & 290 & 63.0 & 63.0 & 63.0 & 105.0 & 108.0 \\
\hline Wheat bran & & 228.7 & 147.7 & 70.0 & 20.0 & 0.00 \\
\hline Urea & & 0.00 & 5.0 & 8.7 & 10.0 & 14.5 \\
\hline Starch & & 32.0 & 108.0 & 182.0 & 353.7 & 491.2 \\
\hline
\end{tabular}

$\mathrm{fNDF}=$ forage neutral detergent fiber; NFC = non-fibrous carbohydrates.

(1990). Neutral detergent fiber (NDF) was determined as described by Mertens (2002), and sulfuric acid lignin as described by Robertson and Van Soest (1981). The NDF content was corrected for ash and protein, and performed according to Licitra et al. (1996) and Mertens (2002).

The NFC were calculated according to Detmann and Valadares Filho (2010): NFC $(\mathrm{g} / \mathrm{kg})=1000-[(\mathrm{CP}$ $-\mathrm{CPU}+\mathrm{U})+\mathrm{NDF}+\mathrm{EE}+\mathrm{ash}$, where: $\mathrm{CPU}$ is the $\mathrm{CP}$ content from urea $(\%)$, and $U$ is the urea content $(\%)$.

Aliquots of the experimental diets ( $350 \mathrm{mg}$ of DM) were packed in $50 \mathrm{~mL}$ glass bottles. McDougall's buffer (McDougall, 1948) was prepared in Erlenmeyer 
Table 3. Chemical composition of the experimental diets.

\begin{tabular}{|c|c|c|c|c|c|c|}
\hline \multirow{2}{*}{ Item (g/kg) } & \multirow{2}{*}{$\begin{array}{l}\text { fNDF } \\
(\mathrm{g} / \mathrm{kg})\end{array}$} & \multicolumn{5}{|c|}{ NFC (g/kg) } \\
\hline & & 350 & 400 & 450 & 500 & 550 \\
\hline $\mathrm{DM}$ & \multirow{7}{*}{100} & 873.7 & 829.7 & 877.6 & 878.6 & 882.2 \\
\hline $\begin{array}{l}\text { Organic } \\
\text { matter }\end{array}$ & & 953.2 & 905.8 & 957.2 & 957 & 960.5 \\
\hline $\begin{array}{l}\text { Crude } \\
\text { protein }\end{array}$ & & 135.4 & 127.4 & 128.8 & 126.9 & 126.4 \\
\hline Ether extract & & 32.1 & 30.4 & 28.1 & 25.1 & 21.8 \\
\hline Ash & & 43.8 & 41.2 & 38.8 & 35 & 32.5 \\
\hline NDF & & 442.4 & 420.4 & 391.8 & 354.4 & 317.6 \\
\hline NFC & & 384 & 417 & 454 & 503 & 542 \\
\hline DM & \multirow{7}{*}{190} & 873.9 & 874.7 & 875.6 & 876.6 & 877.6 \\
\hline $\begin{array}{l}\text { Organic } \\
\text { matter }\end{array}$ & & 957.3 & 958.6 & 958.1 & 957.6 & 957 \\
\hline $\begin{array}{l}\text { Crude } \\
\text { protein }\end{array}$ & & 134.7 & 128.8 & 129.3 & 128.6 & 127.9 \\
\hline Ether extract & & 27.9 & 25.4 & 22.5 & 19.7 & 17 \\
\hline Ash & & 42.7 & 39.5 & 36 & 32.4 & 29 \\
\hline NDF & & 459.3 & 427.7 & 391.4 & 356.6 & 322.8 \\
\hline NFC & & 349 & 401 & 445 & 490 & 535 \\
\hline DM & \multirow{7}{*}{290} & 871.2 & 872.3 & 873.2 & 875.4 & 878.3 \\
\hline $\begin{array}{l}\text { Organic } \\
\text { matter }\end{array}$ & & 959.8 & 958.4 & 958.2 & 957.5 & 955.1 \\
\hline $\begin{array}{l}\text { Crude } \\
\text { protein }\end{array}$ & & 127.6 & 129.1 & 127.4 & 127.7 & 127.7 \\
\hline Ether extract & & 23.1 & 20.2 & 17.4 & 10.1 & 4.7 \\
\hline Ash & & 40.2 & 36.6 & 33.1 & 32.5 & 31.4 \\
\hline NDF & & 473.6 & 437.9 & 403.7 & 340.6 & 296.9 \\
\hline NFC & & 311 & 389 & 434 & 485 & 537 \\
\hline
\end{tabular}

$\mathrm{DM}=$ dry matter; $\mathrm{g} / \mathrm{kg}$ on a fresh matter basis; fNDF = forage neutral detergent fiber; NFC = non-fibrous carbohydrates; NDF = neutral detergent fiber.

flasks, and the $\mathrm{pH}$ was adjusted to 6.8 by saturating it with $\mathrm{CO}_{2}$ gas. To each glass bottle, $28 \mathrm{~mL}$ of McDougall's buffer and $7 \mathrm{~mL}$ of strained ruminal fluid were added. Bottles containing all experimental ingredients were immediately gassed for $10 \mathrm{~s}$ with anaerobic-grade $\mathrm{CO}_{2}$ and then sealed. The final composition of the treatments was $100 \mathrm{mg}$ of forage (DM) in a $10 \mathrm{~mL}$ final solution, and $1 \mathrm{~mL}$ of ruminal fluid in $4 \mathrm{~mL}$ of buffer solution (Tilley and Terry, 1963). Bottles were incubated at $39^{\circ} \mathrm{C}$ for $48 \mathrm{~h}$. The incubation was conducted according to the partial methodology described by Tilley and Terry (1963). The incubation times were $0,3,6,12,24$ and $48 \mathrm{~h}$. The incubation process was repeated three times, generating three evaluations per incubation time for each treatment. Once the fermentations were complete, $1.0 \mathrm{~mL}$ aliquots were collected from each bottle using a syringe with a $0.80 \times 25 \mathrm{~mm}$ needle in order to maintain anaerobic conditions within the tubes (Lana et al., 2000). The $\mathrm{pH}$ was measured using a digital $\mathrm{pH}$ meter (TECNOPON, Piracicaba, SP, BRA). Aliquots were acidified with meta-phosporic acid (one part acid to one part sample) and centrifuged (Hettich Mikro 200 Model, Tuttlingen, BW, GER) at $5200 \times g$ for $10 \mathrm{~min}$. The supernatant was frozen $\left(-20^{\circ} \mathrm{C}\right)$ and subsequently analyzed for volatile fatty acids (VFA) by high performance liquid chromatography (HPLC) according to Siegfried et al. (1984). The HPLC (SPD-10 AVP, Shimadzu Corporation, Osaka, OS, Japan) apparatus was equipped with a refractive index detector and used an Aminex HPX-87H column (BIO-RAD, Hercules, CA, USA) with a mobile phase containing $5 \mathrm{mM} \mathrm{H}_{2} \mathrm{SO}_{4}$ and a flow rate of $0.6 \mathrm{~mL} / \mathrm{min}$ at $50^{\circ} \mathrm{C}$. The VFAs were measured at 0 and $48 \mathrm{~h}$. Molar proportions of VFA were calculated by dividing the concentration of individual acids by the total concentration of VFA. Ammonia was determined by the colorimetric method of Chaney and Marbach (1962). The resulting pellets were washed with a $0.9 \%(\mathrm{w} / \mathrm{v}) \mathrm{NaCl}$ solution, centrifuged at 5200 $\times g$ for $10 \mathrm{~min}$, resuspended in a $0.9 \%(\mathrm{w} / \mathrm{v}) \mathrm{NaCl}$ solution and frozen at $-20^{\circ} \mathrm{C}$. Microbial protein was estimated using the method of Bradford (1976).

At the end of the incubation $(48 \mathrm{~h})$, the residue obtained from each bottle was vacuum filtered in a gooch crucible (gross porosity) and conditioned in bottles $(120 \mathrm{~mL})$ with the addition of $50 \mathrm{~mL}$ of a neutral detergent solution (Mertens, 2002). After sealing, the polyethylene bottles were autoclaved at $105^{\circ} \mathrm{C}$ for $1 \mathrm{~h}$ in order to extract all of the soluble components (neutral detergent micro-extraction method (Pell and Schofield, 1993). After this procedure, the gooch crucibles were again submited to vacuum filtration followed by sequential washing with hot distilled water and acetone. The NDF residue obtained was dried at $105^{\circ} \mathrm{C}$ for $16 \mathrm{~h}$. The NDF digestibility was calculated using the following equation: NDF digestibility $=$ (amount of NDF present in extracted sample bottles) - (amount of NDF in sample after washing)/(amount of NDF present in extracted sample bottles) $\times 100$. 


\section{Statistical analysis}

Data were analyzed using the GLM procedure of SAS software, version 9.4 (SAS Institute, Inc, Cary, NC, USA) (2012). Regression models from different fNDF levels were submitted to a model identity test. The choice of regression equation was based on the determination coefficient and the significance of regression coefficients using the $t$ test, where $\alpha=0.05$.

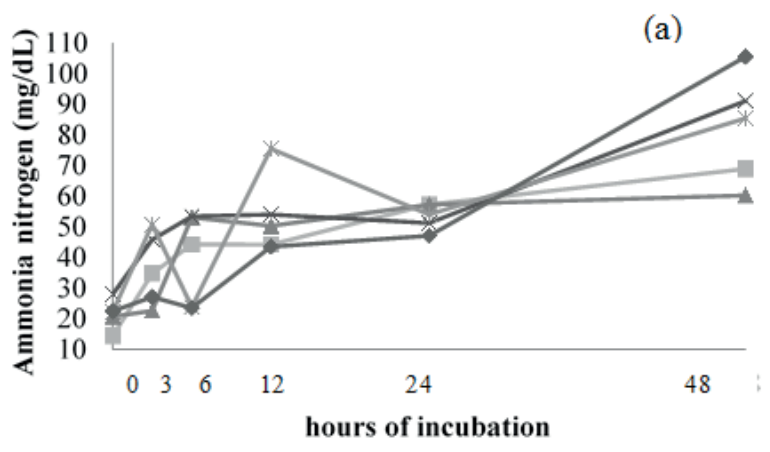

$-350 \mathrm{NFC} \longrightarrow 400 \mathrm{NFC} \longleftarrow 450 \mathrm{NFC} \multimap 500 \mathrm{NFC} \longrightarrow 550 \mathrm{NFC}$

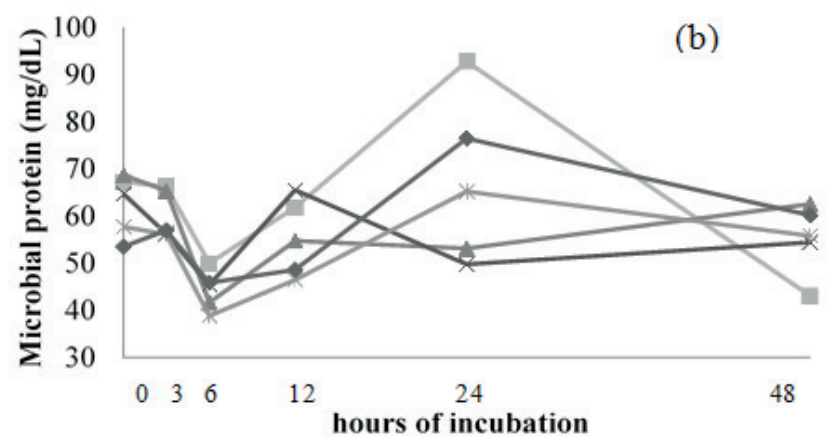

$-350 \mathrm{NFC} \longrightarrow 400 \mathrm{NFC} \longrightarrow 450 \mathrm{NFC} \leadsto-\% 00 \mathrm{NFC} \longrightarrow 550 \mathrm{NFC}$

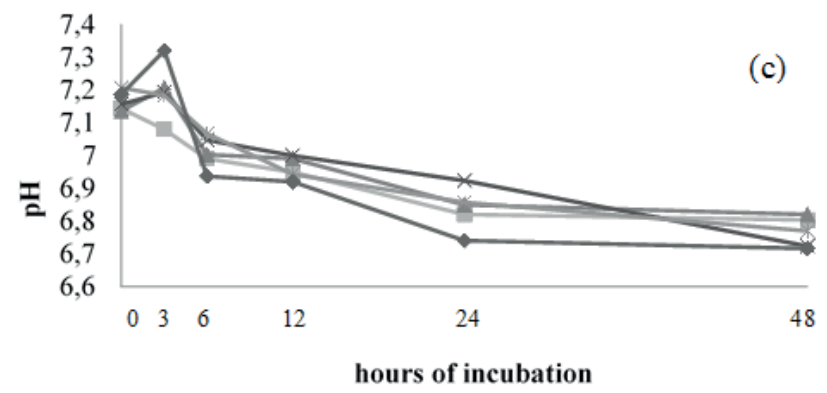

$-350 \mathrm{NFC} \longrightarrow 400 \mathrm{NFC} \longleftarrow 450 \mathrm{NFC} \nsim 500 \mathrm{NFC} \longrightarrow 550 \mathrm{NFC}$

Figure 1. Effect of NFC levels on ammonia (a) and microbial protein (b), and changes in acidity (c) throughout the fermentation time by ruminal microorganisms in diets containing $100 \mathrm{~g} / \mathrm{kg}$ fNDF.

\section{Results}

The ammonia concentration varied throughout the fermentation process as a function of NFC levels in a similar pattern for the three fNDF levels studied, all reaching maximum concentrations after $48 \mathrm{~h}$ (Figures 1a, 2a, and 3a). Microbial protein concentration had a decrease after $24 \mathrm{~h}$ of incubation (Figure 1b, 2b and 3b), except in the diet containing $29 \%$ fNDF with 45 and $55 \%$ NFC.

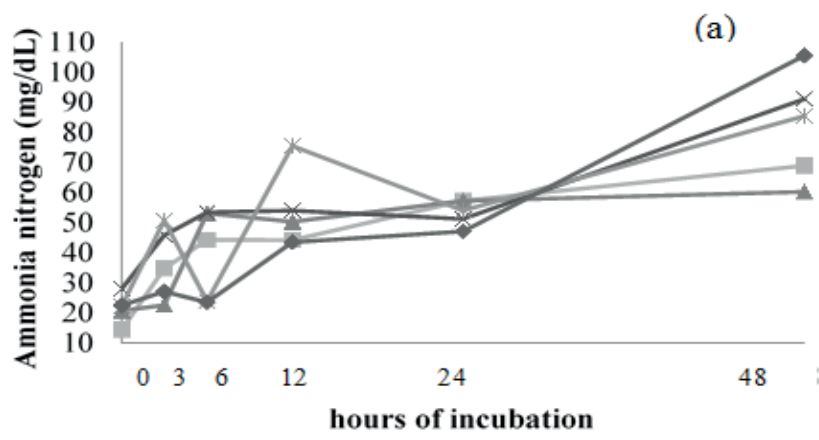

$-350 \mathrm{NFC} \longrightarrow 400 \mathrm{NFC} \longrightarrow 450 \mathrm{NFC} \leadsto 500 \mathrm{NFC} \longrightarrow 550 \mathrm{NFC}$

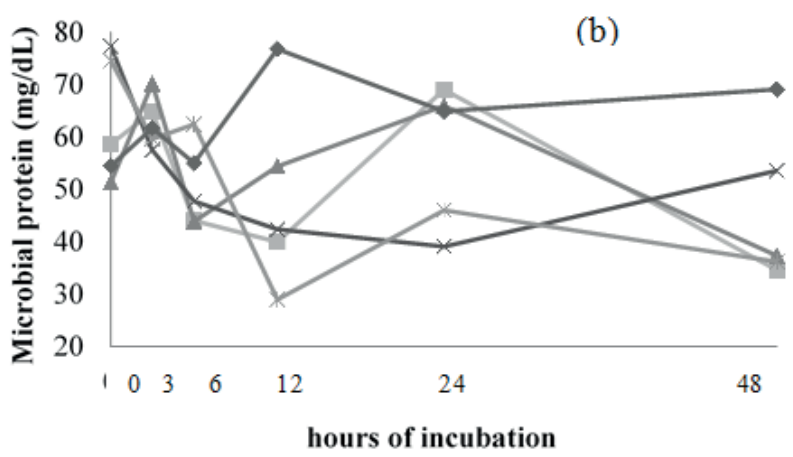

$-350 \mathrm{NFC} \longrightarrow 400 \mathrm{NFC} \longleftarrow 450 \mathrm{NFC} \multimap 500 \mathrm{NFC} \longleftarrow 550 \mathrm{NFC}$

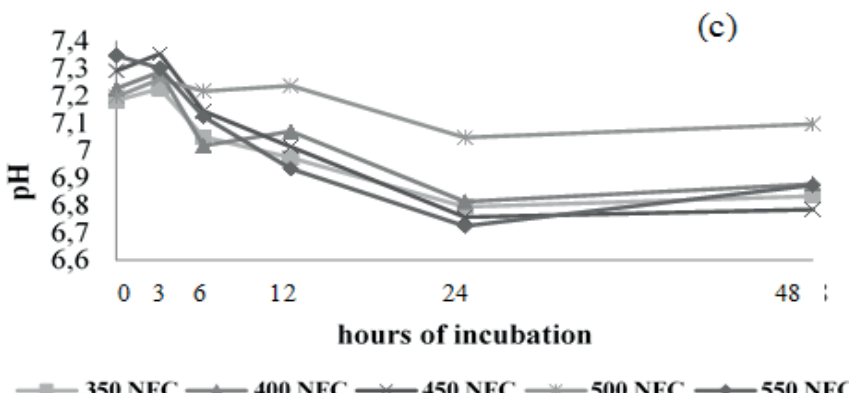

Figure 2. Effect of NFC levels on ammonia (a) and microbial protein (b) concentration, and changes in acidity (c) throughout the fermentation time by ruminal microorganisms in diets containing $190 \mathrm{~g} / \mathrm{kg}$ fNDF. 

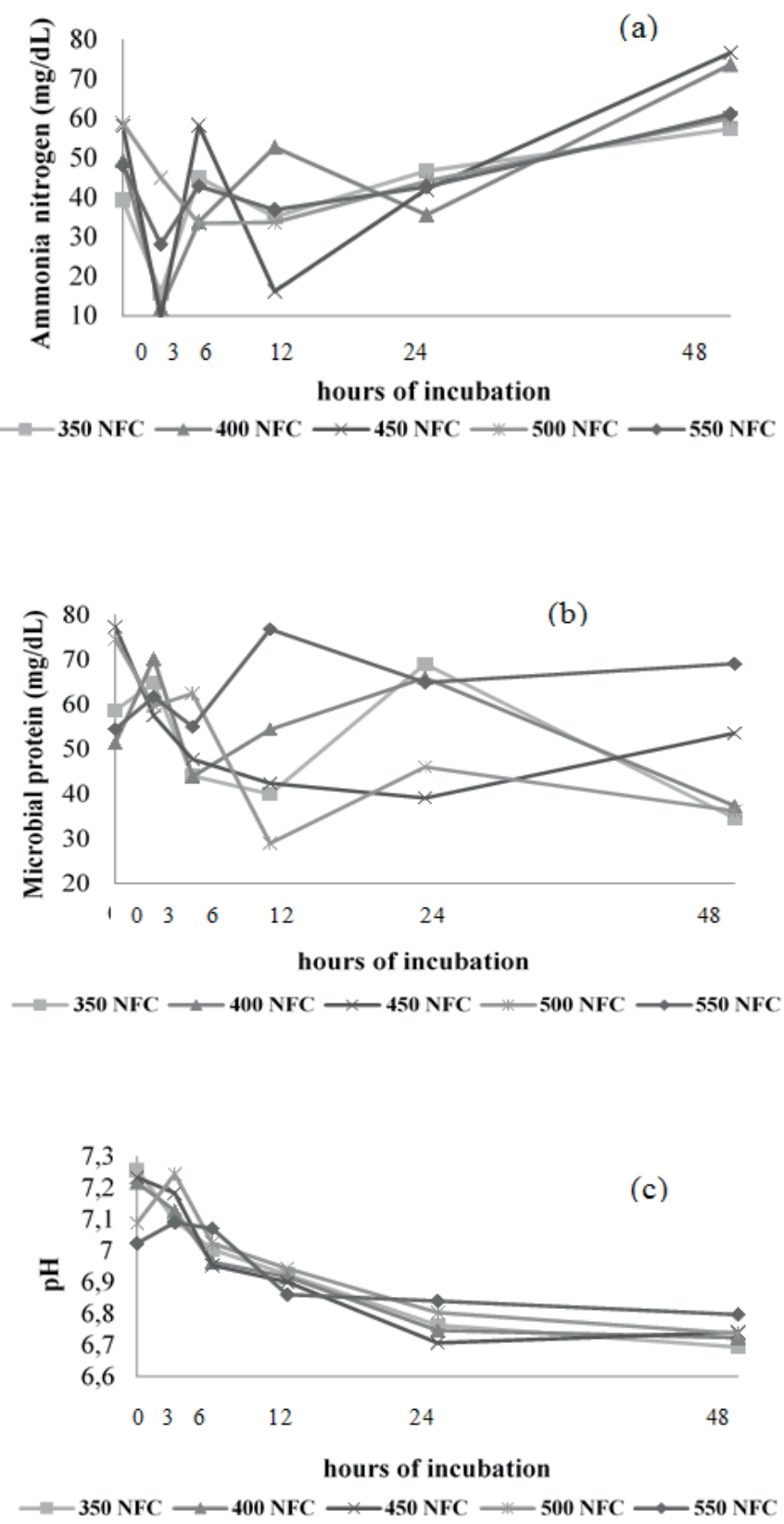

Figure 3. Effect of NFC levels on ammonia (a) and microbial protein (b) concentration, and changes in acidity (c) throughout the fermentation time by ruminal microorganisms in diets containing $290 \mathrm{~g} / \mathrm{kg}$ fNDF.W

Microbial protein concentration after $48 \mathrm{~h}$ of fermentation had a linear crescent effect $(p<0.05)$ on all fNDF levels as a function of increased NFC levels, except for diets containing $190 \mathrm{~g} / \mathrm{kg}$ fNDF (Table 4). When the model identity test was carried out, the linear model of NFC levels for the fNDF levels of 100 and $290 \mathrm{~g} / \mathrm{kg}$ were similar $(\mathrm{p}>0.05)$.

Increasing NFC levels in media containing 100 and $290 \mathrm{~g} / \mathrm{kg}$ fNDF had a linear decrease and increase $(p<0.05)$ in ammonia concentration until $48 \mathrm{~h}$ of fermentation, respectively (Table 4 ). The experimental diet containing $190 \mathrm{~g} / \mathrm{kg}$ fNDF resulted in a quadratic increase $(p<0.05)$ in ammonia concentration as a function of NFC levels. When the model identity test was carried out, the linear models chosen among fNDF levels differed according to the NFC levels $(p<0.05)$. Thus, NFC levels act differently among the fNDF levels in ammonia production. With the exception of media containing $100 \mathrm{~g} / \mathrm{kg} \mathrm{fNDF}$, the increase in NFC levels promoted an increase in the ammonia concentration (Table 4).

Different combinations of $\mathrm{NDF}$ and NFC levels had no effect $(\mathrm{p}>0.05)$ on the $\mathrm{pH}$ (Table 4$)$.

Even with significant increases in total VFA production at $48 \mathrm{~h}$ of fermentation (Table 5), the amount of acid was not enough to decrease the $\mathrm{pH}$.

Total VFA and individual molar ratios were different $(\mathrm{p}<0.05)$ among $\mathrm{fNDF}$ and NFC levels (Table 5). Total VFA concentrations at $48 \mathrm{~h}$ were higher than at $0 \mathrm{~h}$ for all combinations of fNDF and NFC. The diet containing $190 \mathrm{~g} / \mathrm{kg}$ fNDF quadratically increased $(p<0.05)$ total VFA with the addition of NFC; however, a linear increase $(p<0.05)$ was observed in diets containing $290 \mathrm{~g} / \mathrm{kg}$ of fNDF. When the model identity test was carried out, the models of fNDF as function of NFC levels were different $(p<0.05)$. Thus, the change in NFC levels acted differently among the fNDF levels for total VFA production.

In general, significant changes were not observed between the individual molar ratios of acetate, propionate, and butyrate with the addition of NFC at each fNDF level (Table 5). 
Table 4. Effect of forage neutral detergent fiber (fNDF) and non-fibrous carbohydrates (NFC) levels on microbial protein (MP), ammonia concentration and $\mathrm{pH}$ during in vitro fermentation.

\begin{tabular}{|c|c|c|c|c|c|c|c|c|c|}
\hline \multirow{2}{*}{ Item } & \multirow{2}{*}{ fNDF $(g / k g)$} & \multicolumn{5}{|c|}{ NFC $(\mathbf{g} / \mathbf{k g})$} & \multirow{2}{*}{$\begin{array}{l}\text { CV } \\
(\%)\end{array}$} & \multicolumn{2}{|c|}{ P-value } \\
\hline & & 350 & 400 & 450 & 500 & 550 & & $\mathbf{L}$ & $\mathbf{Q}$ \\
\hline \multirow{3}{*}{ MP $0 \mathrm{~h}, \mathrm{mg} / \mathrm{dL}$} & 100 & 577.9 & 712.4 & 692.4 & 522.9 & 585.9 & & - & - \\
\hline & $190^{1}$ & 672.9 & 686.4 & 646.6 & 596.6 & 535.4 & 6.11 & $<0.0001$ & - \\
\hline & $290^{2}$ & 586.1 & 513.0 & 773.5 & 745.7 & 544.4 & & 0.0409 & $<0.0001$ \\
\hline \multirow{3}{*}{ MP 48h, mg/dL } & $100^{3}$ & 283.6 & 435.6 & 526.8 & 588.6 & 657.8 & & $<0.0001$ & - \\
\hline & 190 & 430.8 & 625.8 & 544.5 & 558.1 & 601.8 & 14.29 & - & - \\
\hline & $290^{4}$ & 345.8 & 373.8 & 535.8 & 561.8 & 690.8 & & $<0.0001$ & - \\
\hline \multirow{3}{*}{ Ammonia $0 \mathrm{~h}, \mathrm{mg} / \mathrm{dL}$} & 100 & 329.4 & 407.7 & 309.1 & 507.3 & 396.4 & & - & - \\
\hline & $190^{5}$ & 392.0 & 492.9 & 581.3 & 584.3 & 582.0 & 6.63 & $<0.0001$ & $<0.0001$ \\
\hline & $290^{6}$ & 123.7 & 207.9 & 280.1 & 222.5 & 225.1 & & $<0.0001$ & $<0.0001$ \\
\hline \multirow{3}{*}{ Ammonia $48 \mathrm{~h}, \mathrm{mg} / \mathrm{dL}$} & $100^{7}$ & 893.8 & 791.2 & 859.1 & 791.2 & 662.4 & & $<0.0001$ & - \\
\hline & $190^{8}$ & 573.2 & 735.8 & 765.8 & 600.9 & 610.6 & 7.66 & - & 0.0004 \\
\hline & $290^{9}$ & 689.6 & 603.2 & 910.9 & 855.0 & 1,056 & & $<0.0001$ & - \\
\hline \multirow{3}{*}{$\mathrm{pH} 48 \mathrm{~h}$} & 100 & 6.69 & 6.72 & 6.74 & 6.74 & 6.74 & & - & - \\
\hline & 190 & 6.80 & 6.82 & 6.72 & 6.77 & 6.72 & 0.58 & - & - \\
\hline & 290 & 6.83 & 6.87 & 6.78 & 7.09 & 6.87 & & - & - \\
\hline
\end{tabular}

$\mathrm{MP}=$ microbial protein; fNDF = forage neutral detergent fiber; NFC $=$ non-fibrous carbohydrates.

${ }^{1} \hat{Y}=955.917-0.7297 N F C$

$r^{2}=0.8681$

$2 \hat{Y}=-2575.323+14.3044 N F C-0.156 N F C$

$r^{2}=0.4118$

${ }^{3} \hat{Y}=312.8+1.8029 \mathrm{NFC}$

$r^{2}=0.9572$

${ }^{4} \hat{Y}=238.28+87.72 \mathrm{NFC}$

$r^{2}=0.5158$

$5 \hat{Y}=-1543.843+8.4442 N F C-0.0833 N^{N} C^{2}$

$r^{2}=0.9881$

${ }^{6} \hat{Y}=-1638.181+7.9736 N F C-0.0837 N^{2} C^{2}$

$r^{2}=0.8529$

$7 \hat{Y}=1216.093-0.9256 \mathrm{NFC}$

$r^{2}=0.6826$

${ }^{8} \hat{Y}=-2114.360+12.7561 \mathrm{NFC}-0.1431 \mathrm{NFC}^{2}$

$r^{2}=0.6016$

${ }^{9} \hat{Y}=-63.840+1.9708$ NFC

$r^{2}=0.7508$

$C V=$ Coefficient of variation; $L=$ linear; $Q=$ quadratic. 
Table 5. Effect of forage neutral detergent fiber (fNDF) and non-fibrous carbohydrates (NFC) levels on volatile fatty acids (VFA) concentration and individual molar proportion during in vitro fermentation.

\begin{tabular}{|c|c|c|c|c|c|c|c|c|c|}
\hline \multirow{2}{*}{ Item } & \multirow{2}{*}{ fNDF $(\mathrm{g} / \mathrm{kg})$} & \multicolumn{5}{|c|}{ NFC $(g / k g)$} & \multirow{2}{*}{$\begin{array}{l}\text { CV } \\
(\%)\end{array}$} & \multicolumn{2}{|l|}{ P-value } \\
\hline & & 350 & 400 & 450 & 500 & 550 & & $\mathrm{~L}$ & $Q$ \\
\hline \multirow{3}{*}{ Total VFA Oh, mM } & 100 & 498.9 & 499.7 & 481.9 & 510.4 & 512.7 & \multirow{3}{*}{4.40} & - & - \\
\hline & $190^{1}$ & 563.2 & 509.7 & 514.2 & 528.1 & 612.8 & & 0.0094 & $<0.0001$ \\
\hline & $290^{2}$ & 586.3 & 549.1 & 516.0 & 498.9 & 500.4 & & $<0.0001$ & - \\
\hline \multirow{3}{*}{ Total VFA 48h, mM } & $100^{3}$ & 1,761 & 1,744 & 1,803 & 1,707 & 1,577 & \multirow{3}{*}{2.60} & $<0.0001$ & 0.0008 \\
\hline & $190^{4}$ & 1,666 & 1,550 & 1,664 & 1,787 & 1,884 & & $<0.0001$ & - \\
\hline & $290^{5}$ & 1,796 & 1,771 & 1,660 & 1,476 & 1,473 & & $<0.0001$ & - \\
\hline \multirow{3}{*}{ Acetate $0 \mathrm{~h}, \mathrm{~mol} / 100 \mathrm{~mol}$} & 100 & 522.3 & 531.2 & 528.7 & 528.1 & 527.7 & \multirow{3}{*}{3.68} & - & - \\
\hline & $190^{6}$ & 549.0 & 626.8 & 617.1 & 613.0 & 644.7 & & 0.0001 & - \\
\hline & $290^{7}$ & 638.5 & 627.5 & 657.6 & 607.9 & 570.8 & & 0.0005 & 0.0084 \\
\hline \multirow{3}{*}{ Acetate $48 \mathrm{~h}, \mathrm{~mol} / 100 \mathrm{~mol}$} & $100^{8}$ & 739.3 & 727.3 & 734.1 & 734.8 & 715.2 & \multirow{3}{*}{1.50} & 0.045 & - \\
\hline & 190 & 696.7 & 692.5 & 696.9 & 715.8 & 691.7 & & - & - \\
\hline & 290 & 698.7 & 712.2 & 695.6 & 693.1 & 698.0 & & - & - \\
\hline \multirow{3}{*}{ Propionate $0 \mathrm{~h}, \mathrm{~mol} / 100 \mathrm{~mol}$} & 100 & 280.0 & 260.9 & 269.5 & 271.7 & 272.1 & \multirow{3}{*}{7.02} & - & - \\
\hline & 190 & 248.5 & 230.2 & 248.5 & 237.7 & 213.4 & & - & - \\
\hline & $290^{9}$ & 190.3 & 221.0 & 218.4 & 237.9 & 206.3 & & - & 0.0086 \\
\hline \multirow{3}{*}{ Propionate $48 \mathrm{~h}, \mathrm{~mol} / 100 \mathrm{~mol}$} & 100 & 190.5 & 188.7 & 184.7 & 183.0 & 181.9 & \multirow{3}{*}{4.03} & - & - \\
\hline & 190 & 207.8 & 213.2 & 212.5 & 199.9 & 219.0 & & - & - \\
\hline & $290^{10}$ & 231.0 & 221.0 & 235.1 & 210.6 & 208.7 & & 0.0011 & - \\
\hline \multirow{3}{*}{ Butirate $0 \mathrm{~h}, \mathrm{~mol} / 100 \mathrm{~mol}$} & 100 & 197.6 & 207.8 & 201.8 & 200.1 & 200.1 & \multirow{3}{*}{7.24} & - & - \\
\hline & $190^{11}$ & 202.6 & 143.0 & 134.3 & 149.3 & 141.9 & & $<0.0001$ & $<0.0001$ \\
\hline & $290^{12}$ & 171.3 & 151.4 & 124.0 & 154.2 & 222.9 & & $<0.0001$ & $<0.0001$ \\
\hline \multirow{3}{*}{ Butirate $48 \mathrm{~h}, \mathrm{~mol} / 100 \mathrm{~mol}$} & $100^{13}$ & 70.1 & 840 & 8.2 & 82.2 & 102.9 & \multirow{3}{*}{8.10} & $<0.0001$ & - \\
\hline & 190 & 95.5 & 94.2 & 90.6 & 84.3 & 89.4 & & - & - \\
\hline & $290^{14}$ & 70.3 & 66.8 & 69.3 & 96.3 & 93.3 & & $<0.0001$ & - \\
\hline
\end{tabular}

VFA = volatile fatty acids; fNDF = forage neutral detergent fiber; NFC = non-fibrous carbohydrates.

${ }^{1} \hat{Y}=2053.089-7.1166 \mathrm{NFC}+0.0817 \mathrm{NFC}{ }^{2}$

$r^{2}=0.9746$

$2 \hat{Y}=730.013-0.4441 \mathrm{NFC}$

$r^{2}=0.8839$

${ }^{3} \hat{Y}=-62.033+8.9612 \mathrm{NFC}-0.1085 \mathrm{NFC}^{2}$

$r^{2}=0.8991$

${ }^{4} \hat{Y}=1104.5+1.346 \mathrm{NFC}$

$r^{2}=0.6877$

${ }^{5} \hat{Y}=2482.087-1.8815 \mathrm{NFC}$

$r^{2}=0.9161$

${ }^{\sigma} \hat{Y}=450.443+0.3549 \mathrm{NFC}$

$r^{2}=0.5983$

$7 \hat{Y}=14.720+3.0860 \mathrm{NFC}-0.0377 \mathrm{NFC}^{2}$

$r^{2}=0.8333$

$8 \hat{Y}=766.800-0.0815 \mathrm{NFC}$

$r^{2}=0.4695$

${ }^{9} \hat{Y}=-407.814+2.7344 N F C-0.0293 N^{N F C} C^{2}$

$r^{2}=0.7864$

${ }^{10} \hat{Y}=270.757-0.1099 \mathrm{NFC}$

$r^{2}=0.5433$

${ }^{11} \hat{Y}=980.342-3.5230 N F C-0.0366$ NFC $^{2}$

$r^{2}=0.8220$

${ }^{12} \hat{Y}=1394.071-5.8248 \mathrm{NFC}-0.0671 \mathrm{NFC}^{2} \quad \mathrm{r}^{2}=0.9417$

${ }^{13 \hat{Y}}=26.830+0.1273 \mathrm{NFC}$

$r^{2}=0.7236$

${ }^{14} \hat{Y}=11.220+0.1511 \mathrm{NFC}$

$r^{2}=0.6938$

$C V=$ Coefficient of variation; $L=$ linear; $Q=$ quadratic. 
Changes in $\mathrm{NDF}$ and NFC levels resulted in interaction $(\mathrm{p}<0.05)$ on in vitro NDF digestibility. Only diets containing $290 \mathrm{~g} / \mathrm{kg}$ fNDF had a quadractic relationship $(\mathrm{p}<0.05)$ to increasing NFC levels and in vitro $\mathrm{NDF}$ digestibility with maximum values estimated at $659.6 \mathrm{~g} / \mathrm{kg}$ for $373.2 \mathrm{~g} / \mathrm{kg}$ NFC (Table 6).

Table 6. Effect of forage neutral detergent fiber (fNDF) and non-fibrous carbohydrates (NFC) levels on in vitro NDF digestibility.

\begin{tabular}{|c|c|c|c|c|c|c|c|c|c|}
\hline \multirow{2}{*}{ Item } & \multirow{2}{*}{ fNDF (g/kg) } & \multicolumn{5}{|c|}{ NFC (g/kg DM) } & \multirow{2}{*}{$\mathrm{CV}(\%)$} & \multicolumn{2}{|c|}{$p$-value } \\
\hline & & 350 & 400 & 450 & 500 & 550 & & $\mathbf{L}$ & $\mathbf{Q}$ \\
\hline \multirow{3}{*}{$\begin{array}{l}\text { NDF digestibility } \\
(\mathrm{g} / \mathrm{kg})\end{array}$} & 100 & 635.3 & 646.4 & 648.5 & 647.4 & 658.1 & & ns & ns \\
\hline & 190 & 652.1 & 679.1 & 660.6 & 657.6 & 680.5 & 2.65 & ns & ns \\
\hline & 290 & 658.4 & 651.6 & 649.1 & 607.4 & 565.0 & & 0.0001 & 0.0056 \\
\hline
\end{tabular}

$\mathrm{fNDF}=$ forage neutral detergent fiber; NFC = non-fibrous carbohydrates.

$\hat{Y}=212.67+23.763 C N F-0.315 C N F^{2} \quad r^{2}=0.9845$

$\mathrm{CV}=$ Coefficient of variation; $\mathrm{L}=$ linear; $\mathrm{Q}=$ quadratic.

\section{Discussion}

As in vitro fermentation experiments take place in closed environments, and no ammonia is absorbed through the rumen walls as it occurs in in vivo experiments, the ammonia concentration was directly related to microbial growth since it is used as a nitrogen source for microbial protein synthesis (Russell, 2002; Seo et al., 2010; Seo et al., 2013) (Figures 1a, 2a and 3a).

Thus, we observed that the microbial standard in goats varied more with changes in NFC concentration than changes in fNDF concentration (Figures $1 b, 2 b$ and $3 b$ ). This difference in the rumen environment of goats must be associated with their feeding behavior as they are concentrate pickers and much of their diet comes from less coarse foods. Thus, it is possible that changes in the fNDF concentration less significantly modify the ruminal environment relative to variations in NFC concentration. Similar behavior observed in the three fNDF levels studied reinforces this hypothesis.

Thus, NFC levels affected microbial protein production similarly, regardless of the amount of fNDF contained in the media (Table 4). Thus, we concluded that microbial protein concentration in goats is influenced more by NFC levels than by fNDF levels. Providing a greater amount of rapidly fermentable carbohydrates in the form of NFC created an environment favorable for bacterial growth and increased the amount of energy available to the rumen microoganisms for multiplication
(Russell et al., 1992; Costa et al., 2008; Ma et al., 2014; Ma et al., 2015). Coupled with an increase in energy levels for microbial protein synthesis, ruminal ammonia levels greater than $5 \mathrm{mg} / \mathrm{dL}$ should be an adequate nitrogen source for rumen microrganisms (Satter and Styler, 1974).

The increase in the ammonia concentration, promoted by the increase in NFC levels, may be occur due to the increased amounts of urea added to the experimental diets, as ammonia is produced both by deamination of amino acids and hydrolysis of nonprotein nitrogenous compounds (Valadares Filho and Pina, 2011) (Table 4).

The increase in total VFA was not enough to decrease the $\mathrm{pH}$, probably due to the strong buffering capacity of McDougall's solution (Table 5). Several in vitro studies using this solution reported minor variations in the $\mathrm{pH}$, regardless of the substrate used and whether its degradation was slow or rapid (Costa et al., 2008; Costa et al., 2009; Berthiaume et al., 2010; Purcell et al., 2014).

We expected an increase in the concentration of total VFA as NFC levels increased; however this was not observed for the fNDF levels 100 and $290 \mathrm{~g} / \mathrm{kg}$ (Table 5). Under ideal conditions with excess fNDF, providing more rapidly fermentable carbohydrates promoted the growth of fermenting NFC microrganisms and increased VFA concentrations in the media (Vieira et al., 2008). Berthiaume et al. (2010) and Ma et al. (2015) observed similar 
increases in total VFA concentration when the NFC/ NDF ratio was improved. However, increased NFC concentrations in the media may not influence or even decrease the total VFA concentration due to a simultaneous increase in fNDF concentration or total NDF in the diet (Archimede, 1996; CantalapiedraHijar et al., 2009).

The absence of significant changes in individual molar ratios of acetate, propionate and butirate may have occurred due to small variations on $\mathrm{H}^{+}$ concentrations, which affect $\mathrm{pH}$ and the metabolic pathways of some microrganisms. In this case, the metabolic fermentation pathways of microrganisms were not modified, which would have interfered with the production of acetate and propionate (Russel, 2002; Jiang et al., 2013); thus the proportions of these metabolites were similar in the different combinations of fNDF and CNF studied. Russel (1988) reported that some ruminal microrganisms are capable of producing acetate and propionate in combination with other products such as formate, ethanol and $\mathrm{CO}_{2}$, and that a change in acidity is capable of modifying the fermentation metabolic pathways of microrganisms (Aschenbach et al., 2011; Castillo-González et al., 2014). As an example, when fermentation is slow and extracellular $\mathrm{pH}$ is near neutral, Streptococcus bovis produces acetate, formate and ethanol, which are products of primary fermentation when growth rate is slow (Russel, 1988; Castillo-González et al., 2014). These products were produced by the enzyme pyruvate formate lyase. On the other hand, if extracellular and intracellular $\mathrm{pH}$ declines, as is the case with more rapidly fermentable carbohydrates available than what is needed to increase growth rate, the pyruvate produced is converted into lactate. In this specific case, the change in metabolic pathways and the change in fermentation end products happens because pyruvate lyase becomes inactive at low $\mathrm{pH}$ (Russel, 2002).

Studies reported changes in the proportions of the main VFA, where low and high NFC/NDF ratios are evaluated in sheep (Ma et al., 2015), and goat (Cantalapiedra-Hijar et al., 2009). In contrast, Costa et al. (2008) did not find changes in the proportions of the mains VFA. In this last study, authors noted that there was no rapid degradation of carbohydrates, which was indicated by the high $\mathrm{pH}$. Thus, $\mathrm{pH}$ is an important variable that responds to variations of the main VFA in the rumen. As observed in this study, the absence of $\mathrm{pH}$ variation did not cause significant changes in VFA molar ratios, even at high NFC/NDF ratios.

Diets with high NFC/NDF ratio resulted in lower NDF digestibility, probably due to the decline in $\mathrm{pH}$ (Cantalapiedra-Hijar et al., 2009; White et al., 2010; Ma et al., 2015) that directly impacted how different microbial groups ferment carbohydrates (Homen Júnior et al., 2015). Increased VFA production caused a decrease in $\mathrm{pH}$ and inhibited growth of bacteria that ferment fibrous carbohydrates, thus compromising NDF digestibility (Van Soest, 1994; Krajcarski-Hunt et al., 2002; Sung et al., 2007; Cerrato-Sánchez et al., 2008 Russell et al., 2009). However, in the present study, the minimum $\mathrm{pH}$ value observed was approximately 6.70 (Figure 1c). It likely did not decrease significantly due to the buffering capacity of the media, and there was not a decrease in NDF digestibility when higher NFC concentrations were used (Table 6).

In conclusion, the relationship between fNDF and NFC concentrations affects fermentation end products and in vitro NDF digestibility. The NFC levels appear to play a more consistent role over rumen microbial ecosystem during in vitro fermentation. Changes in the microbial standard of goats during in vitro fermentation are more affected by changes in NFC concentrations than fNDF concentrations. Thus, a reduction in NFC levels will allow goat diet formulations with minimum levels of NDF.

\section{Conflict of interest}

The authors declare that they have no conflict of interests with regard to the work presented in this report.

\section{References}

AOAC. Official methods of analysis. Association of Official AnalyticaL Chemists. 15 ${ }^{\text {nd }}$ ed. Washington, DC, USA. 1990.

Archimede H, Sauvant D, Hervieu J, Ternois F, Poncet C. Effects of the nature of roughage and concentrate and their proportion on ruminal characteristics of non lactating goats, consequences on digestive interactions. J Anim Sci Technol 1996; 58:267-282. 
Aschenbach JR, Penner GB, Stumpff F, Gäbel G. Ruminant Nutrition Symposium: Role of fermentation acid absorption in the regulation of ruminal pH. J Anim Sci 2011; 89:1092-1107.

Berthiaume R, Benchaar C, Chaves AV, Tremblay GF, Castonguay Y, Bertrand A, Bélanger G, Michaud R, Lafreniére C, McAllister TA, Brito AF. Effects of nonstructural carbohydrate concentration in alfalfa on fermentation and microbial protein synthesis in continuous culture. J Dairy Sci 2010; 93:693-700.

Bispo SV, Ferreira MA, Véras ASC, Batista AMV, Pessoa RAS, Bleueu MP. Palma forrageira em substituição ao feno de capimelefante. Efeito sobre consumo, digestibilidade e características de fermentação ruminal em ovinos. Rev Bras Zootecn 2007; 36 : 1902-1909.

Bradford MM. A rapid and sensitive method for the quantitation of microgram quantities of protein utilizing the principle of proteindye binding. Anal Biochem 1976; 72:248-254.

Branco RH, Rodrigues MT, Rodrigues CAF, Silva MMC, Leão MI, Pereira VV. 2010. Efeito dos níveis de fibra em detergente neutron oriunda de forragem sobre a eficiência microbiana e os parâmetros digestivos em cabras leiteiras. Rev Bras Zootecn 2010; 39:372-381.

Branco RH, Rodrigues MT, Silva MMC, Rodrigues CAF, Queiroz AC, Araújo FL. Desempenho de cabras em lactação alimentadas com dietas com diferentes níveis de fibra oriundas de forragem com maturidade avançada. Rev Bras Zootecn 2001; 40:1061-1071.

Cantalapiedra-Hijar G, Yáñez-Ruiz DR, Martín-García AI, Molina-Alcaide E. Effects of forage: concentrate ratio and forage type on apparent digestibility, ruminal fermentation, and microbial growth in goats. J Anim Sci 2009; 87:622-631.

Castillo-González AR, Burrola-Barraza ME, Domínguez-Viveros J, Chávez-Martínez A. Rumen microorganisms and fermentation. Arch Med Vet 2014; 46:349-361.

Cerrato-Sánchez M, Calsamiglia S, Ferret A. Effect of the magnitude of the decrease of rumen $\mathrm{pH}$ on rumen fermentation in a dual-flow continuous culture system. J Anim Sci 2008; 86:378-383.

Chaney AL, Marbach EP. Modified reagents for determination of urea and ammonia. Clin Chem 1962; 8:130-132.

Costa SF, Pereira MN, Melo LQ, Caliari MV, Chaves ML. Alterações morfológicas induzidas por butirato, propionato e lactato sobre a mucosa ruminal e epiderme de bezerros. II. Aspectos ultraestruturais. Arq Bras Med Vet Zootec 2008; 60:10-18.

Costa RC, Beltrão Filho EM, Medeiros AN, Givisiez PEN, Queiroga RCRE, Melo APS. Effects of increasing levels of cactus pear (Opuntia ficus-indica L. Miller) in the diet of dairy goats and its contribution as a source of water. Small Rumin Res 2009; 82:65-65.

Detmann E, Valadares Filho SC. On the estimation of non-fibrous carbohydrates in feeds and diets. Arq Bras Med Vet Zootec 2010; 62:980-984.

Finlaysson HJ. The effect of $\mathrm{pH}$ on the growth and metabolism of Streptococcus bovis in continuous culture. J Appl Microbiol 1986; 71:201-208.
Homem Júnior AC, Ezequiel JMB, Perez HL, Almeida MTC, Paschoaloto JR, Carvalho VB, Cremasco LF, Costa MB. In vitro fermentation of corn silage using rumen fluid buffered or not and different sample amounts. Cienc Rural 2015; 45:2229-2232.

Jiang J, Zhang Y, Li K, Wang Q, Gong C, Li M. Volatile fatty acids production from food waste: Effects of $\mathrm{pH}$, temperature, and organic loading rate. Biores Technol 2013; 143:525-530.

Krajcarski-Hunt H, Plaizier JC, Walton JP, Spratt R, McBride BW. Short communication: Effect of subacute ruminal acidosis on in situ fiber digestion in lactating dairy cows. J Dairy Sci $2002 ; 85: 570-573$

Lana RP, Cunha LT, Borges AC, Mantovani HC. Desenvolvimento de uma técnica para determinação da degradabilidade da proteína dos alimentos para ruminantes. Rev Bras Zootecn 2000; 29:2119-2127.

Licitra G, Hernandez TM, Van Soest PJ. Standardization of procedures for nitrogen fractionation of ruminant feeds. Anim Feed Sci Technol 1996; 57:347-358.

Lu CD, Kawas JR, Mahgoub OG. Recent advancements in fiber digestion and utilization in goats. Trop Subtrop Agroecosyst 2008; 9:65-72.

Ma T, Deng KD, Tu Y, Jiang CG, Zhang NF, Li YL, Si BW, Lou C, Diao QY. Effect of dietary concentrate: forage ratios and undegraded dietary protein on nitrogen balance and urinary excretion of purine derivatives in dorper thin-tailed han crossbred lambs. Asian-Australas J Anim Sci 2014; 27:161-168.

Ma T, Tu Y, Zhang NF, Deng KD, Diao QY. Effect of the ratio of non-fibrous carbohydrates to neutral detergent fiber and protein structure on intake, digestibility, rumen fermentation, and nitrogen metabolism in lambs. Asian-Australas J Anim Sci $2015 ; 28: 1419-1426$.

McDougall EI. Studies on ruminant saliva. I. The composition and output of sheep's saliva. J Biochem 1948; 43:99-109.

Mertens DR. Gravimetric determination of amylase-treated neutral detergent fiber in feeds with refluxing in beakers or crucibles: collaborative study. J AOAC Int 2002; 85:1217-1240.

National Research Council. Nutrient requirements of dairy cattle. $7^{\text {nd }}$ ed. Washington (DC): National Academy Press; 2001.

National Research Council-NRC. 2007. Nutrient Requirements of Small Ruminants. Washington (DC): National Academy Press; 2007.

Oliveira AS, Detmann E, Campos JMS, Pina DS, Souza SM, Costa MG. Meta-análise do impacto da fibra em detergente neutro sobre o consumo, a digestibilidade e o desempenho de vacas leiteiras em lactação. Rev Bras Zootecn 2011; 40:1587-1595.

Oliveira JS, Queiroz AC, Mantovani HC, Detmann E, Santos EM, Silva TC. Evaluation of whey fermented by Enterococcus faecium in consortium with Veilonella parvula in ruminant feeding. Rev Bras Zootecn 2012; 41:172-180.

Pell AN, Schofield P. Computerized monitoring of gas production to measure forage digestion in vitro. J Dairy Sci 1993; 76:1063-1073.

Purcell PJ, Boland TM, O'Kiely P. The effect of water-soluble carbohydrate concentration and type on in vitro rumen methane 
output of perennial ryegrass determined using a 24-hour batchculture gas production technique. J Agric Res 2014; 53:21-36.

Reid R, Ljung GA, Cox-Ganser JM, Rybeck BF, Townsend EC. Comparative utilization of warm- and cool-season forages by cattle, sheep and goats. J Anim Sci 1990; 68:2986-2994.

Robertson JB, Van Soest PJ. The detergent system of analysis. In: James WPT, Theander O, editors. The Analysis of Dietary Fibre in Food. NY: Marcel Dekker; 1981. p.123-158.

Russel JB. Ecology of rumen microorganisms: energy use. In: Dobson A, Dobson M editors. Aspect of digestive physiology in ruminants. Ithaca: Comstock; 1988. p.74-98.

Russell JB, O'Connor JD, Fox DG, Van Soest PJ, Sniffen CJ. A net carbohydrate and protein system for evaluating cattle diets. I. Ruminal fermentation. J Anim Sci 1992; 70:3551-3561.

Russell JM. Rumen microbiology and its role in ruminant nutrition. Ithaca (NY): Cornell University Press; 2002.

Russell JB, Muck RE, Weimer PJ. Quantitative analysis of cellulose degradation and growth of cellulolytic bacteria in the rumen. Fems Microbiol Ecol 2009; 67:183-197.

SAS $^{\circledR}$, Statistical Analysis Systems. SAS/STAT User's guide. Version 9.4. Cary (NC, USA): SAS Institute Incorporation; 2012.

Seo JK, Kim MH, Yang JY, Kim HJ, Lee CH, Kim KH, Ha JK. Effects of Synchronicity of Carbohydrate and Protein Degradation on Rumen Fermentation Characteristics and Microbial Protein Synthesis. Asian-Aust J Anim Sci 2013; 26:358-365.

Seo JK, Yang JY, Kim HJ, Upadhaya SD, Cho WM, Ha JK. Effects of synchronization of carbohydrate and protein supply on ruminal fermentation, nitrogen metabolism and microbial protein synthesis in Holstein steers. Asian-Aust J Anim Sci 2010; 23:1455-1461.

Siegfried VR, Ruckermann H, Stumpf G. Method for the determination of organic acids in silage by high performance liquid chromatography. Landwirt Forsch 1984; 37:298-304.
Silva DJ, Queiróz AC. Análise de alimentos: métodos químicos e biológicos. $2^{\text {nd }}$ ed. Viçosa $(\mathrm{MG})$ : Universidade Federal de Viçosa; 2002.

Sniffen CJ, O'Connor DJ, Van Soest PJ, Fox DG, Russell JB. A net carbohydrate and protein system for evaluating cattle diets: carbohydrate and protein availability. J Anim Sci 1992; 70: 3562-3577.

Strobel HJ, Russel JB. Effects of $\mathrm{pH}$ and energy spilling on bacteria protein synthesis by carbohydrates cultures of mixes rumen bacteria. J Dairy Sci 1986; 69:2941-2947.

Sung HG, Kobayashi Y, Chang J, Ha A, Hwang IH, Ha JK. Low ruminal ph reduces dietary fiber digestion via reduced microbial attachment. Asian-Aust J Anim Sci 2007; 20:200-207.

Tilley JMA, Terry RA. A two-stage technique for the in vitro digestion of forage crops. J Br Grassl Soc 1963; 18:104-111.

Valadares Filho SC, Pina DS. Fermentação Ruminal. In: Berchielli TT, Pires AV, Oliveira SG editors. Nutrição de Ruminantes. $2^{\text {nd }}$ ed. Jaboticabal: FUNEP; 2011. p.161-191.

Valadares Filho SC, Machado PAS, Chizzotti ML, Amaral HF, Magalhães KA, Rocha Júnior VRR, Capelle ER. CQBAL 3.0. Tabelas Brasileiras de Composição de Alimentos para Bovinos. [access date November 12, 2015) URL: http://www.ufv.br/cqbal

Van Soest PJ. Nutritional ecology of the ruminant. $2^{\text {th }}$ ed. Ithaca(NY): Comstock Publishing Association; 1994.

Vieira EL, Batista AMV, Guim A, Carvalho FF, Nascimento AC, Araújo RFS, Mustafa AF. Effects of hay inclusion on intake, in vivo nutrient utilization and ruminal fermentation of goats fed spineless cactus (Opuntia ficus-indica Mill) based diets. Anim Feed Sci Technol 2008; 141:199-208.

Xu J, Hou Y, Yang H, Shi R, Wu C, Huo Y, Zhao G. Effects of forage sources on rumen fermentation characteristics, performance, and microbial protein synthesis in midlactation cows. Asian-Australas J Anim Sci 2014; 27:667-673. 